\title{
The Working Methods of the International Law Commission
}

\author{
Maurice Kamto
}

\section{I Introduction}

The working methods of the Commission are an area of old concern. From 1986, the General Assembly repeatedly emphasized that the Commission should re-examine the way it selects the topics it wishes to deal with, as well as the methods and procedures it uses to conduct its work. ${ }^{1}$ On the occasion of its fiftieth anniversary, in 1998, the Commission organized a major colloquium in New York around the general theme "Making Better International Law: The International Law Commission at 50" (hereinafter the "1998 colloquium"), an important part of which dealt with the choice of topics and the working methods of the Commission. ${ }^{2}$ The issues at the heart of the matter have not changed since then. The question is whether the Commission has been able to take advantage of the comments and suggestions made by the participants in the 1998 colloquium, most of whom have become members of this august institution. To answer this question, I will endeavour to review the various questions on the part of the programme of this colloquium devoted to the working methods of the Commission, notably: Should the Commission adapt its working methods to the outcomes of its work? How has the communication with other bodies and persons changed and how could it be improved? The role of Special Rapporteurs; the role of the Drafting Committee; the role of commentaries; the role of the Codification Division; and other support.

I will not engage in a theoretical appraisal of these different points. I will examine the issues raised in the light of my almost two decades of practical experience in the Commission, as a member, Special Rapporteur and Chair of the

1 UNGa Res 41/81 (3 December 1986); Res 42/156 (7 December 1987); Res 43/169 (9 December 1988); Res 44/35 (4 December 1989); Res 45/41 (28 November 199o); Res 46/54 (9 December 1991); Res 47/33 (25 November 1992); Res 48/31 (9 December 1993); Res 49/51 (9 December 1994); and Res 50/45 (11 December 1995).

2 United Nations, Making Better International Law: The International Law Commission at 50. Proceedings of the United Nations Colloquium on Progressive Development and Codification of International Law (United Nations 1998) 101 et seq. 
Commission, focusing on three topics: the working methods in relation to the outcomes of work (II), the role of Special Rapporteurs and of the Codification Division (III) and the role of the Drafting Committee (IV).

\section{On the Working Methods in Relation to the Outcomes of Work}

\section{A Adaptation of the Working Methods and the Commission's Final Product}

The question of whether the Commission should adapt its working methods to the outcomes of its work did not arise in the past, and, in any case, was not a matter of major concern. This is because, until recent years, the outcomes of the work of the Commission almost exclusively took the form of draft articles. The Commission did not devote much discussion on the issue, even after the introduction of new products in its practice, like guidelines, principles, conclusions and reports of study groups. ${ }^{3}$

Some people think that the form of the final product of the Commission's work does not affect its methods of work. The practice of the Commission tends to validate such an assertion, simply because the Commission has never really considered the matter. The consequence is that we find ourselves in a situation where the same methods of work lead to different products. The Commission would benefit from clarifying the situation and adapting its working methods to the type of final product it intends to adopt. This requires that the type of product to be elaborated be chosen early enough, if possible within the framework of the discussions on the topic in the working group on the long-term programme of work, and in any case no later than in the preliminary or first report of the Special Rapporteur on the topic. The plenary debates of the Commission on this report should focus not only on the substantive orientation of the topic, but also on its final product; this way, the Sixth Committee has an opportunity to express its views on the choice of the expected product at the same time as it comments on a particular topic.

Although the choice of the type of final product cannot be considered immutable, it is desirable that it not be called into question once Special Rapporteurs have embarked on their treatment of the topic, because, in my opinion, the method chosen will have to depend on the expected final product. In fact, contrary to current practice, it seems to me that it would be judicious

3 See, respectively, n 9, n 10 and n 11. 
to introduce a methodological differentiation between the elaboration of draft articles and the elaboration of guidelines, principles and conclusions, let alone reports of study groups. For example, while the language of draft articles should be imperative, even when engaging in progressive development of international law, the formulation of guidelines, principles or conclusions may be a little looser. Indeed, in the context of the draft articles, rules formulated by way of progressive development are typically drafted in terms of legal obligation. These provisions have the same firmness as rules falling within the ambit of codification in the strict sense of the word, that is, the formulation and systemization of rules of customary international law. On the other hand, the enunciation of a legal norm in the framework of guidelines, principles or conclusions is often done in the subjunctive in French or in aspirational terms in English, which does not imply a legal obligation but rather indicates what is desirable. Admittedly, it might exceptionally be the case that an aspirational provision, indicating to States what is desirable, is included in a draft article. A good example is article 19 of the draft articles on diplomatic protection, which offers guidance as to "recommended practice" with regard to the exercise of diplomatic protection. ${ }^{4}$ But draft article 19, introduced at the last minute in the draft articles by the Special Rapporteur and without debate in plenary, was the result of a compromise, and the Commission rarely uses this approach in the context of draft articles to further the progressive development of international law. Fundamentally, the advantage of distinguishing working methods according to the envisaged final product is that such a distinction makes it possible, in certain cases, to introduce a degree of normative flexibility in the Commission's output. Granted, the risk that this methodological differentiation may lead to the production of depreciated by-products is not negligible. But in the absence of such a methodological differentiation, it would be difficult to explain why the Commission's unique working methods lead to the development of different products from the point of view of both the final form and the legal authority of the Commission's work.

\section{B Final Form of the Work}

As to the final form of the work, divergent views have been expressed in the Commission and in debates in the Sixth Committee. That was particularly the case when some Special Rapporteurs suggested that the final form of the work on their topic should be draft articles. ${ }^{5}$

4 ILC, 'Draft articles on diplomatic protection' [2006] II (2) ILC Ybk 24.

5 See, for instance, Maurice Kamto, 'Eighth report on the expulsion of aliens' (2012) UN Doc A/CN.4/651 15, para 55-57; Shinya Murase, 'Annex II. Protection of the atmosphere' 
While reports of study groups more closely resemble an academic project than an exercise in progressive development and codification of international law, the nature of guidelines, principles and conclusions is more difficult to clarify. These categories of final products of the work of the Commission have gained ground within the Commission in recent years. Since 1998, the Commission's work on three topics on its agenda has taken the form of guidelines, ${ }^{6}$ three that of principles (including guiding principles) ${ }^{7}$ and five that of conclusions (two of which were formulated by study groups). ${ }^{8}$ These forms, which seem to be well-established both within the Commission and the Sixth Committee of the General Assembly, and even outside it, raise theoretical, methodological and legal questions. These questions concern, first, the distinction between guidelines, principles and conclusions (including reports of

[2011] II(2) ILC Ybk 189 (proposing that the topic result in draft articles) and ILC, 'Other decisions and conclusions of the Commission' (2013) UN Doc A/68/10 para 168 (recording the "understanding" of the Commission that "[ $\mathrm{t}]$ he outcome of the work on the topic will be draft guidelines that do not seek to impose on current treaty regimes legal rules or legal principles not already contained therein"); and Marie G. Jacobsson, "Third report on the protection of the environment in relation to armed conflicts' (2016) UN Doc A/CN.4/700 para 24 and 51 .

6 See ILC, 'Guide to practice on reservations to treaties'[2011] II(3) ILC Ybk 23; ILC, 'Draft guidelines on the protection of the atmosphere, together with preamble, adopted by the Commission on first reading' (2018) UN Doc A/73/10, 158; ILC, 'Draft guide to provisional application of treaties, adopted by the Commission on first reading' (2018) UN Doc A/73/ 10,203 .

7 ILC, 'Draft principles on the allocation of loss in the case of transboundary harm arising out of hazardous activities' [2006] II(2) ILC Ybk $5^{8}$; ILC, 'Guiding principles applicable to unilateral declarations of States capable of creating legal obligations' [2006] II(2) ILC Ybk 160; ILC, 'Draft principles on protection of the environment in relation to armed conflicts provisionally adopted so far by the Commission' (2018) UN Doc A/73/10, 246 (currently under consideration).

8 ILC, 'Conclusions of the work of the Study Group on the Fragmentation of International Law: difficulties arising from the diversification and expansion of international law' [2006] II(2) ILC Ybk 177. 'The Most-Favoured-Nations clause' (2015) UN Doc A/70/10, 17, 19 (listing the summary conclusions adopted); 'Draft conclusions on subsequent agreements and subsequent practice in relation to the interpretation of treaties' (2018) UN Doc A/73/10, 12; 'Draft conclusions on identification of customary international law' (2018) UN Doc A/ 73/10, 119; Conclusions on peremptory norms of international law (jus cogens) (currently under consideration, see UN Doc A/73/10, 224); Conclusions on general principles of law (currently under consideration, see ILC, 'Annex A. General principles of law' (2017) UN Doc $\mathrm{A} / 72 / 10,224)$. The members proposing the topic "Sea-level rise in relation to international law", included in the long-term programme of work in 2018, envisage a set of "conclusions" to be worked out by a Study Group, if added to the agenda of the Commission; see ILC, 'Annex B. Sea-level rise in relation to international law' (2018) UN Doc A/73/10, 326, 331 at para 26. 
study groups); and, second, the distinction between draft articles and other outcomes.

a) Distinction between Guidelines, Principles and Conclusions

From a theoretical perspective, the search for a criterion of distinction between guidelines, principles and conclusions may be in vain. Since none of them are draft articles, we are inclined to think that they are intended to guide States or to give them guidance or even guidelines on what international law would or could be in a specific area. But if so, why use different terms? Does this mean that there could be a difference in the level of authority between these types of products? For example, would a conclusion be firmer than a guideline, or vice versa? A principle more authoritative than a guideline? What then about "guiding principles"?

From a methodological perspective, the Commission follows the same working methods for guidelines, principles and conclusions, consisting of the designation of a Special Rapporteur, who produces draft provisions. These then go through the same process of plenary debates, followed by the drafting of normative statements by the Drafting Committee, and then the report of the Drafting Committee to the plenary, which adopts the final text of the guidelines, principles or conclusions. The Special Rapporteur produces successive reports according to the same requirements of quality and recourse to treaties, State practice and international jurisprudence. The Commission has, so far, not established precise and objective criteria to determine whether the final product of its work on a topic should be draft guidelines, principles or conclusions. This could be considered arbitrary, inspired by the impression, whether founded or not, of a hierarchy of importance between topics, an impression that is even more pronounced when the terminological distinction is between draft articles, on the one hand, and draft guidelines, principles or conclusions, on the other. If the same working methods and the same scientific and methodological requirements apply to the development of these different final products, what would really justify the terminological distinction between them? The Commission should answer this question, in order to help the Special Rapporteurs in the approach to be followed according to the expected final result, and the users of its work to see clearly the respective status of these legal products.

From a legal point of view, it is not easy to determine the respective authority of the guidelines, principles and conclusions, or to say how the authority of the one would be different from that of the others. An example of the confusion that this creates can be found in the debate concerning the Commission's work on the draft guidelines contained in the Guide to practice on reservations 
to treaties. ${ }^{9}$ Would guidelines, principles or conclusions constitute legal advice - and nothing more - whose appreciation of whether to resort to it would be at the discretion of States? What is the added value of such outcomes? And how do they relate to binding rules of international law, contained in treaties or customary international law?

b) Distinction between Draft Articles, on the One Hand, and Guidelines, Principles and Conclusions, on the Other

In theoretical terms, my experience in the Commission leads me to suggest that draft articles are considered as the consummate expression of the current state of international law on the given topic. They would include, on the one hand, the crystallization of the rules of customary international law through codification and, on the other hand, the rules that the Commission considers to be emerging, on the basis of a thorough study of State practice by the Special Rapporteur for a long enough period of time and supported by the research and advice of the Codification Division of the United Nations Office of Legal Affairs, the comments and criticisms of other codification bodies with or without cooperation arrangements with the Commission, international organizations, non-governmental organizations specialized in the relevant field, as well as academic experts. The Commission thus appears both as an indicator of the law, in this case customary international law, which it reveals in a well-tested manner (even if its methodology is not without criticism), and as a quasi-legislator, because of the power it is given to formulate rules on the basis of often scattered material. Nowhere does it say that the guidelines, principles and conclusions relate to another type of exercise or that they are different products. However, it seems that this is the perception that the official recipients (United Nations Member States) and the Commission's unofficial audience (the different users of the Commission's work) have.

On the methodological side, however, the elaboration of draft articles, guidelines, principles and conclusions strictly follows the same working methods within the Commission, as described in the preceding paragraph: appointment of a Special Rapporteur on the topic, production of reports and formulation of draft provisions, which go through the same process of plenary debates followed by the elaboration of a provisional text by the Drafting Committee, and then the report of the latter to the plenary that adopts the final text of the draft articles, guidelines, principles or conclusions.

9 ILC, 'Reservations to treaties' [1997] II(2) ILC Ybk 46, 52-53. 
From the point of view of legal scope, could the idea underlying the diversification of categories relate to the distinction between progressive development and codification, so that the draft articles would be the expression of the lex lata, while the guidelines, principles and conclusions would reflect lex feren$d a$ ? Such a distinction would not be well-founded, since draft articles may also contain lex ferenda as part of the progressive development of international law. However, the terminological differentiation leads to the feeling that with draft articles, we are dealing with a kind of quasi-treaty whose provisions might be binding on States, even if the draft articles themselves have no binding force. The development of a practice of recourse by international or even national courts to the draft articles of the Commission, which the General Assembly has taken note of, and sometimes even before the Assembly does so, tends to make States wary of the special or ad hoc legal status of the Commission's draft articles. Moreover, it inclines them to consider draft articles with circumspection and to caution their support. It is not uncommon for some States to express, in their statements during the debates of the Sixth Committee, real reservations with regard to draft articles submitted by the Commission. On the other hand, States would appear to be more comfortable with products such as guidelines, principles and conclusions, the naming of which seems to diminish their legal significance. This is undoubtedly why some members of the Commission, anxious to see the final products of the Commission accepted more easily by States, pushed the Commission, perhaps even unconsciously, towards these substitute products. The idea must be that powerful States could accept them more easily, these States being typically inclined to reject draft articles that could be invoked against them without their signature or ratification, thus without their formal consent, perhaps even against their will. Thus, when these States do not want international rules on a topic, they may demand that, if the topic is not abandoned, it be dealt with in the form of guidelines, principles or conclusions. It does not matter that international law provides material for codification, let alone progressive development in the relevant field. The work of the Commission on the expulsion of aliens is emblematic in this respect. While the Sixth Committee had itself approved the inclusion of the topic on the Commission's agenda for the preparation of draft articles, ${ }^{10}$ a handful of powerful States, with influential connections within the Commission, did their best, first to defeat the codification of the topic, and then, facing the failure of this objective, to impose the abandonment of the form of draft articles in favour of draft principles, general principles or guiding principles. As I have said 
on several occasions, it is up to the Commission, which is an expert body, to do the technical work of codification and progressive development, in short to say on every topic on its programme of work what the established or relevant rules of international law are. The General Assembly must do legal policy, among other things by choosing the final form to give to the work of the Commission. Each body should stick to its own responsibilities and competencies.

The diversity of terms for the final products of the Commission's work is puzzling to some users of this work. In particular, it does not make it easier for judges, especially national judges, who may not know what to think of outcomes whose scope may seem merely clarificatory, particularly as regards conclusions. Although it may be thought that guidelines and principles are more prescriptive, the fact remains that they are no more than what their name says: guidelines or principles whose purpose is to guide the legal practice of States, without, however, having to consider the exact scope of legal obligations. It is doubtful whether teachers and researchers are more comfortable with these terminologies.

There is a danger that conclusions, including the reports of study groups, or even guidelines and principles, could lead to the classification of the products of the Commission's work as doctrine of the most qualified publicists of different nations, within the meaning of paragraph $1(\mathrm{~d})$ of Article 38 of the Statute of the International Court of Justice. However, it must be maintained that, when the outcome takes the form of draft articles, the work of the Commission cannot fall into this category; in this form they are more than doctrine, but constitute lex ferenda from the formal point of view (instrumentum), comprising, on the substantive level (negotium), lex lata rules as declaratory of customary law. Moreover, whether the rules contained in draft articles of the Commission are lex lata or lex ferenda, they enjoy a high authority, in no way comparable to the doctrine of publicists, even if they are the most qualified of the different nations. After all, the Commission's power of enunciation or formulation of the law of the community of States is exercised through the United Nations General Assembly, of which it is a subsidiary body. According to article 1 of its statute, it should be recalled that the Commission "shall have for its object the promotion of the progressive development of international law and its codification". It is undoubtedly this assessment of the nature and level of legal authority of the Commission's work that explains why various international jurisdictions, in particular the International Court of Justice, do not hesitate to rely with confidence on the work of the Commission in the motivation of their decisions. The exchange between the Commission and the Court is from this point of view exemplary and revealing of the mutual respect which the two institutions have for each other and attach to their respective work. 
Will the Court rely on the Commission's other outcomes with the same confidence and legal certainty as draft articles? It is clear that in the case of the former, there is less certainty about their legal status. States and international courts may not be willing to accept these outcomes of the Commission's work in the same way as draft articles. They will have to distinguish between what falls under the Commission's normative power (draft articles) and what flows from its doctrinal capacity (conclusions, reports of study groups, even guidelines and principles).

It is not a question of saying that the Commission should only produce draft articles. The diversification of the Commission products makes it possible to enrich its work by dealing with topics that it would be unable to address, if it were to be limited exclusively to the production of draft articles. However, the Commission must not unduly dilute what constitutes its singular identity as the highest-level technical codification body in the international system. Codification, which may include elements of the progressive development of international law, is a normative process, not merely a doctrinal one. What is feared is that, with the proliferation of doctrinal products, to the detriment of those of codification and the progressive development of international law, the work of the Commission will be assimilated - as some authors wrongly do - to doctrine. The so-called "new" products created by the Commission should be limited to a few topics of major importance to the international community and where there is a real need for legal clarification, but which does not offer a sufficient degree of maturity to proceed with codification, or even progressive development based on significant trends in State practice.

The conclusions and recommendations of the 1998 colloquium of the Commission show that

the distinction between codification and progressive development is difficult if not impossible to draw in practice; the Commission has proceeded on the basis of a composite idea of codification and progressive development. Distinctions drawn in its Statute between the two processes have proved unworkable and could be eliminated in any review of the Statute (...).11

On this basis, it might also be considered that the distinction between draft articles, guidelines, principles and conclusions is not entirely relevant and that the Commission should stick to its good old practice of elaborating draft

11 United Nations (n 2) 376. 
articles, a product known and appreciated by the community of States and international lawyers. However, since the diversification of outcomes may have been a condition for the survival of the Commission, there is reason to believe that a total reversal of the course of recent Commission practice may not be easy. As we have explained above, a clarification of methodology in relation to the final products developed by the Commission could allow it to maintain the current terminological diversity while avoiding the confusion it creates in people's minds.

\section{The Role of the Special Rapporteur and the Codification Division}

\section{A The Central Role of the Special Rapporteur in the Treatment of the Topic}

The 1998 colloquium offered an opportunity to reflect extensively on the role of a Special Rapporteur. The statute does not seem to envisage the appointment of a Special Rapporteur for all topics, or for all aspects of a topic. It

only expressly envisages such an appointment in the case of projects for progressive development. But from the very first, the practice of the Commission has been to appoint a Special Rapporteur very early in the consideration of a project and to do so without regard to whether the project might be classified as one of codification or progressive development. ${ }^{12}$

The practice of distributing rapporteurships among members from different regions should be preserved, although it is crucial that the competence and ability to perform the work expected of a Special Rapporteur be the decisive criterion in the selection of the Commission. This regional diversification in the designation of Special Rapporteurs has many advantages, "in particular in that it helps to ensure that different approaches and different legal cultures are brought to bear in the formulation of reports and proposals. ${ }^{\text {"13 }}$

It has been noted in the past "that Special Rapporteurs have tended, or even been expected, to operate in isolation from the Commission, with little guidance during the preparation of reports on the direction of future work."14 I do not think that this is the case now. Most of the recommendations made during the 1998 colloquium concerning the work of the Special Rapporteurs have been

\footnotetext{
12 Ibid at $386-387$. See also article 16 of the statute of the ILC.

13 Ibid at 387 .

14 Ibid.
} 
implemented, and practice in recent years shows that Special Rapporteurs are aware that they are serving the Commission for the topics for which they have been designated. Even though Special Rapporteurs may want to maintain a certain degree of intellectual independence in the treatment of their topics, they tend to seek the Commission's approval of their reports and generally take the utmost account of the majority's observations and opinions within the Commission. However, there have been occasional sensitivities of some Special Rapporteurs to certain views outside the Commission, the obvious purpose of which is to influence the course of the topic's treatment. As long as such opinions are based on a thorough analysis of the prevailing state of international law, there is no reason to complain. On the other hand, it would be unfortunate and damaging to the work and image of the Commission as an expert body, if some actors would use this body to advance a social or ideological cause, or to achieve their own legal policy agenda. The Commission is not meant to enunciate primary rules, aimed at constraining the sovereign power of States; the Commission's mandate is to codify and progressively develop secondary rules, providing the foundation and basic structure of the international legal framework.

Regarding the reports of Special Rapporteurs and the timetable of work for a given topic, it seems important that the guidance or instruction to Special Rapporteurs should be provided very early, if necessary after the first report or preliminary report. In this respect, while the need for some independence of Special Rapporteurs is understandable, impartiality ought to be the rule, and it is essential that future reports of the Rapporteurs should meet the needs of the Commission as a whole. The first report, which should enable Special Rapporteurs to present in a substantial way their understanding of the topic, the direction they intend to give to their treatment and the methodological approach, is an opportunity for the Commission to set out the necessary framework for the treatment of the topic. It is at this stage that the "consultative group", advocated in the recommendations of the 1998 colloquium, ${ }^{15}$ should be brought in, or a working group established, if necessary, to help Special Rapporteurs to get on with their topic. Indeed, in 1998, it appeared that "in most cases the practice has been for the Special Rapporteur to work largely in isolation in preparing reports. In other words, in the period between sessions a Special Rapporteur has no formal contact with other members of the Commission."16 Other bodies, such as the International Law Association and the Institut de

\footnotetext{
15 Ibid at 388 .

16 Ibid.
} 
Droit International, work differently and with undeniable effectiveness, thanks to the ongoing exchanges between the members of the commissions created for each topic during the intersessional period. Indeed, in these bodies,

[v]arious members are chosen to act as a consultative group so that, between sessions, the Rapporteur may consult over the best and most acceptable approach to be taken, and over the essential elements to the next report. Through questionnaires, the circulation of reports or exceptionally the holding of interim meetings, the group's advice is available. Although the report remains that of the Rapporteur, it is likely that the input obtained will ensure that it is acceptable to the membership of the committee and by extension to the membership of the body as a whole. $^{17}$

This practice could also be implemented within the Commission, on the one hand, without drawing a distinction between codification and progressive development as the statute suggests, and, on the other hand, without any formalism, which makes it possible to adapt it on a case-by-case basis. The Commission may not have to exactly reproduce the practice of the above-mentioned institutions. For example, it is doubtful whether it is advisable to set up an advisory group for the duration of a session, or even the treatment of a topic. The current practice of the Commission seems more suitable for its flexibility in determining its duration and the variation of its composition, which are always determined in consultation with the Special Rapporteur. The possibility of consultations outside the session should also be considered, excluding organising physical meetings, which would necessarily entail financial costs that the budget of the Commission may not be able to bear. It worth recalling and stressing that, even with such a consultative or working group, the report will remain the responsibility of the Special Rapporteur, rather than of the group. It is not the function of the group to approve the Special Rapporteur's report, but to provide input on its general direction and on any particular issues the Special Rapporteur wishes to raise.

The topic's treatment plan should be presented in the first report of the Special Rapporteur, to enable the Commission to have an overview and to ensure that important aspects of the topic are not lost sight of. Of course, a work plan is never engraved in marble and must be adjusted if necessary, without the Special Rapporteur being able to bear the blame.

17 Ibid. 
Special Rapporteurs should make their reports available before the beginning of the session. The experience has shown that the practice is not uniform: some reports are circulated in advance of the session, some are not; and more so, some have even been circulated only days before of their scheduled consideration, even though this has been an exception. This is not caused only by delays in translation and circulation due to financial constraints on the United Nations or to its rules for documentation, which are, of course, beyond the control of a Special Rapporteur, but sometimes by the latter themselves. This is very detrimental to the work of the Commission, as these delays do not allow proper consideration of the report by its members. It is highly desirable that all reports should be available to Commission before, or at the latest at, the beginning of the session.

\section{B The Valuable Support of the Codification Division}

While the Special Rapporteurs play a central role in dealing with the topics on the agenda of the Commission, the Codification Division, as its secretariat, is the linchpin of the Commission's work. In addition to its role in reminding the Commission of its rules and practices, and in suggesting solutions to thorny procedural problems, the Codification Division is making a vital contribution in two areas: its memoranda on subjects studied, and its assistance to Special Rapporteurs in the preparation of comments on draft articles, guidelines, principles or conclusions.

Regarding its memoranda, upon the appointment of a Special Rapporteur on a topic on the Commission's agenda, the Codification Division prepares a study on the subject, generally as comprehensive as possible. This highly informed research, both on the prevailing state of international law (conventional and customary) and on jurisprudence, State practice and doctrine, is invaluable. Of course, it hardly exempts the Special Rapporteurs from their own research on the subject. However, in many ways, it complements the Special Rapporteurs' research, helps them to orient themselves better in their topic and provides them with material that they would have a hard time bringing together for themselves: State practice. It is important that this research assistance provided by the Codification Division be maintained, especially since some Special Rapporteurs do not have the means to afford the assistance of a team of young university researchers. For some members of the Commission from developing countries, particularly those in Africa, the difficulty in securing the assistance of a research team is a reason for reluctance to seek the office of Special Rapporteur. In my experience, the Secretariat's studies can help them at least partially overcome this obstacle.

With regard to the preparation of comments on draft articles, guidelines, principles or conclusions, the assistance of the Secretariat is also crucial. The 
experience gained in this area greatly facilitates the task of the Special Rapporteurs, who, without such assistance, or that of teams of academics who may assist Special Rapporteurs from developed countries or working in those countries, would devote a much longer time, and would delay the progress of the Commission's work.

The commentaries also form a valuable part of the travaux préparatoires of any treaty provision that may be adopted on the basis of the proposed text. The main function of a commentary is to explain the text itself, with appropriate references to key decisions, doctrine and State practice, so that the reader can see the extent to which the Commission's text reflects or, as the case may be, develops or extends the law. According to the practice of the Commission, it is not the function of the commentaries to reflect disagreements on the text as adopted on second reading; this can be done in plenary at the time of final adoption of the text and will then be appropriately reflected in the report of the Commission to the General Assembly. As the Statute makes clear, draft articles should not be considered finally adopted without the Commission having approved the commentaries before it.

\section{The Role of the Drafting Committee}

The Drafting Committee is a crucial forum within the Commission. It is, as its name indicates, the place where the final product of the Commission is drafted, where the draft texts of the Special Rapporteur and the suggestions made by the members of the Commission during the plenary debates are used to formulate draft articles, guidelines, principles or conclusions. Whereas the plenary has the general policy power of the Commission, the Drafting Committee has the technical power, which in practice is binding on the plenary; because, except in the event of disagreement between the Drafting Committee and the plenary on a major question, the plenary usually approves the report of the Drafting Committee. This is to say that the Drafting Committee is the decisive place of preparation of the products of the Commission. Members of the Commission who want to influence the development of the final product of the Commission sit on it systematically. It is significant in this respect that the members of the Commission from the major world powers sit on the Drafting Committee for all topics. On the other hand, members of developing countries are, unfortunately, barely present in the work of the Drafting Committee and tend to limit their participation in the work of the Commission to plenary meetings. It is therefore not surprising that their impact on the final products of the Commission is extremely low. They are absent from the place where 
the provisional statements of the Special Rapporteur take their final form, and where the proposals made in plenary are shaped into concrete provisions. Here the absentees are in the wrong.

The Chair of the Drafting Committee plays a major role in the conduct of the work of the Committee. Not only does the Chair maintain the speakers list and manage the time, he or she also has to sniff out the direction in which the discussions are going, in order to quickly summarize the debates and to propose, if necessary, compromise formulas. In good practice, Chairs must ensure that their proposals are in keeping with the Special Rapporteur's position, or that the latter is not strongly opposed to it. Occasionally, some Chairs overwhelm the Drafting Committee's work with their personality, or are so directive that they come to impose their personal position. However, in general, the Chair knows how to advance the Committee's work by ensuring the fair consideration of the initial drafts of the Special Rapporteur, any new proposals by the Special Rapporteur made following the discussions in the plenary, and drafting proposals and other suggestions made by members of the Commission in plenary.

The Drafting Committee is, equally, where the independent voice of the Special Rapporteur has to be harmonized with the range of views within the Commission. The demands of particular topics, and the approach of particular Special Rapporteurs, will always produce some diversity of practice. It is in the Drafting Committee that divergent views on a topic are most clearly expressed and have to be reconciled. The Special Rapporteur must accept the view of the Drafting Committee as a whole, even if it is contrary to his or her own views, and, as necessary, reflect the view of the Drafting Committee in revised articles and commentaries. In performing his or her function, the Special Rapporteur should act as servant of the Commission rather than a defender of any personal views. In practice, the Drafting Committee amends, redrafts, splits or merges the draft articles, guidelines, principles or conclusions proposed by the Special Rapporteur. It generally adopts the new draft by consensus; only in rare cases does it do so by a vote among the members present. As was explained in 1998,

[o]f course, a Special Rapporteur who disagrees with the eventual views of the Drafting Committee has every right to explain the disagreement in plenary when the report of the Drafting Committee is presented. It is open to the plenary to prefer the views of the Special Rapporteur to those of the Drafting Committee in such a case. Having regard to the size of the Drafting Committee and to its role vis-à-vis the plenary, however, there are likely to be few such cases. Moreover, it is better for major disagreements which cannot be resolved in the Drafting Committee to 
be reported at an earlier stage to the plenary, with the possibility of an indicative vote to settle the matter (...). ${ }^{18}$

Contrary to the earlier practice of the Commission, it is now not unusual for draft articles to be referred to the Drafting Committee without commentaries having been prepared. More so, draft articles are sometimes presented for final consideration by the Commission without commentaries, and the commentaries are only adopted, with little time for consideration, in the final stages of a session. It can be argued that, since the draft articles are likely to be changed substantially in the Drafting Committee, the provision of commentaries by a Special Rapporteur in advance is premature. On the other hand, it has been suggested that the Drafting Committee is in a much better position if it has available to it at the same time both draft articles and commentaries (or at least an outline of what the commentaries will contain). However, not only is it difficult for the Special Rapporteur to provide both at the same time, due to the burden of work that it implies; it also seems to me that the reports of the Special Rapporteur provide at this stage sufficient information that can help both the plenary and the Drafting Committee to understand the scope and purpose of the draft articles, guidelines, principles or conclusions. Indeed, the commentaries help to explain the purpose of the draft articles and to clarify their scope and effect. From my own experience, I do not share the view that the provision of draft articles alone precludes flexibility in resolving disagreement over some aspect of a draft, by the transfer of some provision from the text to the commentary or vice versa. The Drafting Committee will ask the Special Rapporteur to proceed that way and the Chair of the Drafting Committee will include such a request in the Committee's report to the plenary.

\section{Conclusion}

An examination of the Commission's current practice shows that it took into account most of the recommendations made at the end of the Commission's 1998 colloquium, marking its fiftieth anniversary. One of the important issues that the Commission would benefit from clarifying is the form of the final product of the Commission's work. In the absence of such clarification, the proliferation of products without differentiation of their status could seriously affect the authority and reputation of the Commission. At a time when it

18 Ibid at 39 o. 
attracts external criticism, mostly unjustified, the Commission must make the occasion of its seventieth anniversary the starting point of a new aggiornamento of its methods of work, the contribution it intends to make to international law and the type of outcomes it intends to discuss with the Sixth Committee and the General Assembly. It is very worrying that no more draft articles of the Commission have led to the convening of a diplomatic conference for their transformation into an international convention. The importance of the International Law Commission should be reaffirmed through the choice of topics and the quality of its work. 